\title{
Impact of body mass index on clinical outcomes associated with percutaneous nephrolithotomy
}

\author{
Fahad A. Alyami, MD; Thomas A. A. Skinner, MSc; Richard W. Norman, MD, FRCSC
}

Department of Urology, Dalhousie University, Halifax, NS

Cite as: Can Urol Assoc J 2013;7:E197-E201. http://dx.doi.org/10.5489/cuaj.11229. Epub 2012 May 15.

\section{Abstract}

Introduction: Percutaneous nephrolithotomy (PCNL) is the preferred treatment for patients with large renal calculi or stones that have not responded to extracorporeal shock wave lithotripsy (ESWL). The objective of this study was to compare outcomes and complications of PCNL in patients of various body mass indices (BMI) to determine the safety of this procedure in patients with elevated BMI.

Methods: A retrospective chart review of 114 patients who underwent PCNL between 2006 and 2009 was performed. Patients were separated into 4 groups with respect to their BMI: (1) ideal body weight (BMI $<25 \mathrm{~kg} / \mathrm{m}^{2}$ ), (2) overweight (BMW 25-29 kg/m²), (3) obese (BMI $30-39 \mathrm{~kg} / \mathrm{m}^{2}$ ) and (4) morbidly obese (BMI $\geq 40 \mathrm{~kg} / \mathrm{m}^{2}$ ). One-way ANOVA and univariate logistic regression analysis were used to assess the association between BMI (classified into 4 levels) and variables including age, sex, stone size, length of stay, incidence of complications and stone-free rates.

Results: The distribution of the 114 patients in each BMI category was: ideal body weight 39 (34\%), overweight 24 (21\%), obese 41 $(36 \%)$, morbidly obese $10(9 \%)$. There was no difference in the composition of groups with respect to age, sex, pharmacologically treated comorbidities or stone size. Mean length of stay in days, intra- and postoperative complication rates were not statistically different. Stone-free rates showed no significant difference between groups: $90 \%$ ideal body weight; $87 \%$ overweight; $90 \%$ obese; $80 \%$ morbidly obese $(p=0.83)$.

Interpretation: Outcomes of PCNL were statistically independent of BMI. PCNL is a safe and efficacious treatment of stone disease in patients of all sizes.

\section{Introduction}

An increasingly sedentary lifestyle and high fat diet have resulted in obesity reaching pandemic status in the western world. Currently, more than one third of the American population and one quarter of Canadians are obese. ${ }^{1}$ There is significant regional variation of this trend, with over $60 \%$ of Atlantic Canadians being overweight or obese, $10 \%$ more than the national average. ${ }^{2}$ Individuals with elevated body mass index (BMI) are at an increased risk of cardiovascular complications, malignancies, metabolic derangements and premature death. ${ }^{3}$ Furthermore, obesity and weight gain have been demonstrated to increase the risk of nephrolithiasis., ${ }^{4,5}$ Several studies have also shown obesity to be an independent risk factor for surgical and anesthetic complications, including thromboembolic events, atelectasis and wound infections. ${ }^{6-9}$ To help surgeons select patients appropriately, risk and outcome data are needed for each type of surgical procedure on patients of varying BMI.

Extracorporeal shock-wave lithotripsy (ESWL) is the preferred method to treat small- and medium-sized renal calculi; however, this technique is less efficacious in obese patients, even when adjustments are made to the treatment protocol. ${ }^{10}$ For larger stones $(\geq 2 \mathrm{~cm}$ ) or for patients who are not candidates for, or have failed ESWL, percutaneous nephrolithotomy (PCNL) is the primary treatment modality. Given the decreased effectiveness of ESWL, PCNL has also become popular to treat renal calculi in patients with elevated BMI. This approach poses several treatment challenges in obese patients because they do not easily tolerate prone positioning and the thicker subcutaneous fat layer can render nephroscopes too short. ${ }^{11}$ Studies examining the efficacy and safety of PCNL in obese and morbidly obese patients are limited and show mixed results. ${ }^{12-14}$

Many urologists are reluctant to operate on patients with elevated BMI, however as obesity rates increase, the burden of stone disease is also expected to rise. ${ }^{4,5}$ We compared outcomes and complications of PCNL in patients of various BMI to determine the safety of this procedure in patients with elevated measurements. 


\section{Methods}

Retrospective chart review was performed on all patients with BMI data who underwent PCNL between 2006 and 2009. They were stratified according to their BMI into one of four standardized group definitions: ideal body weight $\left(\mathrm{BMI}<25 \mathrm{~kg} / \mathrm{m}^{2}\right.$ ), overweight (BMI $25-29 \mathrm{~kg} / \mathrm{m}^{2}$ ), obese (BMI $\left.30-39 \mathrm{~kg} / \mathrm{m}^{2}\right)$ and morbidly obese $\left(\mathrm{BMI} \geq 40 \mathrm{~kg} / \mathrm{m}^{2}\right)$.

PCNL was performed using a multidisciplinary approach. Gentamicin was given intravenously at the beginning of the procedure and 8 hours later in patients with normal renal function. The affected ureter was cannulated by a urologist and a ureteric catheter was left in place to facilitate percutaneous access by an interventional radiologist in the radiology suite, where access to all imaging modalities was available. The tract was dilated with Amplatz (Cook Medical, Bloomington, IN) dilators to a diameter of $12 \mathrm{~F}$ to facilitate the insertion of a high-pressure balloon dilator with a 30F sheath (Nephromax, Boston Scientific, Boston, MA). The stones were removed by graspers with or without ultrasonic/pneumatic lithotripsy. Once complete clearance of the targeted stones was confirmed by fluoroscopy and flexible nephroscopy, a $20 \mathrm{~F}$ to $24 \mathrm{~F}$ nephrostomy tube (NT) was introduced into the kidney under fluoroscopic guidance and sutured to the skin. Re-entry versus non re-entry NT was selected according to the surgeon's preference. The Foley catheter and the NT remained connected to straight drainage overnight. If the patient was stable and afebrile overnight, the NT was clamped at 6 am for 4 hours and then removed if there was no change and the patient was discharged. No nephrostogram was done in these cases. If pain or fever $\left(>38^{\circ} \mathrm{C}\right)$ developed following clamping, the NT was unclamped and another trial of clamping was done the next day. If pain and/or fever recurred, the NT was unclamped and a nephrostogram was done once the pain and/or fever settled. Any further intervention was dependent on these findings. Patients were given analgesics, non-steroidal antiinflammatories and/or narcotics as needed. Vital signs were done routinely. All patients had a complete blood count,

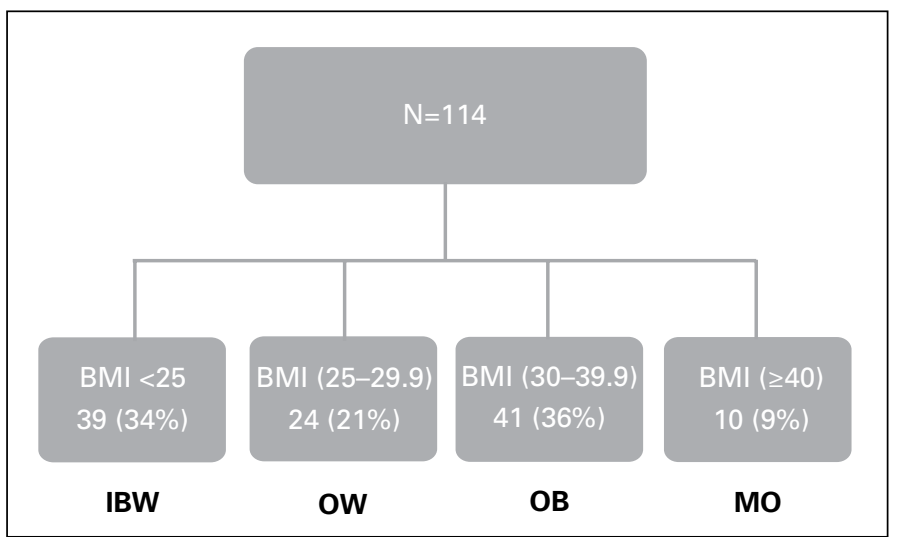

Fig. 1. Distribution of patients by body mass index. BMI: body mass index. electrolytes and serum creatinine done on the morning following surgery.

Preoperative, intraoperative and postoperative factors were compared across groups to assess for selection bias and compare outcomes. Preoperative variables included age, gender, BMI, stone size, stone location, stone side, presence of staghorn calculi, prior surgical intervention for stone disease (ESWL vs. PCNL), pharmacologically treated comorbidities and preoperative hemoglobin $(\mathrm{Hb})$ and glomerular filtration rate (GFR). Intraoperative factors assessed were operating room (OR) time and intraoperative complications. Postoperative analysis included targeted stone-free rate, length of hospital stay, need for readmission and postoperative complications, $\mathrm{Hb}$ and GFR.

Demographic and perioperative data were reported as mean \pm standard error of the mean (SEM) for quantitative variables. One-way ANOVA was used to determine the association between BMI categories and continuous patient characteristics. Univariate logistic regression analysis was used to assess the association between BMI categories and patient characteristics. All tests were evaluated at a 0.05 significance level. Statistical analyses were performed using SAS/STAT Release 9.2 (SAS Institute, Inc., Cary, NC). Complications were graded from 1 to 5 in a standardized fashion, according to the Clavien classification system.

Table 1. Characteristics of patient and stone parameters and previous treatments

\begin{tabular}{|c|c|c|c|c|c|}
\hline Variable & $\begin{array}{c}<25 \\
N=39\end{array}$ & OW & $\begin{array}{c}\text { OB } \\
\text { BMI } \\
30-39.9\end{array}$ & $\begin{array}{c}\mathrm{MO} \\
\mathrm{BMI} \geq 40 \\
\mathrm{~N}=10\end{array}$ & \\
\hline $\begin{array}{l}\text { Mean age } \\
\text { (years) }\end{array}$ & $55(2.6)$ & $60(2.8)$ & $60(2.2)$ & $53(4.1)$ & $0.1^{*}$ \\
\hline \multicolumn{6}{|l|}{ Gender } \\
\hline Male & 23 & 10 & 15 & 5 & 0.2 \\
\hline Female & 16 & 14 & 26 & 5 & $* *$ \\
\hline $\begin{array}{l}\text { Mean stone size } \\
(\mathrm{cm})\end{array}$ & $\begin{array}{c}2.3 \\
(0.14)\end{array}$ & $\begin{array}{c}2.3 \\
(0.2)\end{array}$ & $\begin{array}{c}2.2 \\
(0.16)\end{array}$ & $\begin{array}{c}2.4 \\
(0.39)\end{array}$ & $0.9 *$ \\
\hline \multicolumn{6}{|l|}{ Stone location } \\
\hline Upper pole & 2 & 1 & 0 & 1 & \\
\hline Middle pole & 1 & 0 & 1 & 0 & 0.4 \\
\hline Lower pole & 10 & 12 & 14 & 2 & $* *$ \\
\hline Pelvicalyceal & 1 & 0 & 0 & 0 & \\
\hline Pelvic & 24 & 10 & 26 & 7 & \\
\hline \multicolumn{6}{|l|}{ Stone side } \\
\hline Right & 18 & 7 & 18 & 3 & 0.6 \\
\hline Left & 21 & 17 & 22 & 7 & $* *$ \\
\hline Staghorn stones & $17(43 \%)$ & $9(37 \%)$ & $12(29 \%)$ & $3(30 \%)$ & $\begin{array}{l}0.5 \\
* *\end{array}$ \\
\hline Struvite stones & $5(13 \%)$ & $\begin{array}{c}3 \\
(12.5 \%)\end{array}$ & $5(12 \%)$ & $1(10 \%)$ & $\begin{array}{l}0.9 \\
* *\end{array}$ \\
\hline \multicolumn{6}{|l|}{ Previous surgery } \\
\hline ESWL & 13 & 9 & 14 & 4 & 0.5 \\
\hline PCNL & 4 & 0 & 5 & 0 & $* *$ \\
\hline
\end{tabular}


Table 2. Number of pharmacologically treated common comorbidities in each BMI group

\begin{tabular}{lccccc}
\hline & IBW & OW & OB & MO & $\boldsymbol{p}$ value \\
\hline Hypertension & 12 & 10 & 21 & 5 & 0.3 \\
Diabetes mellitus & 5 & 2 & 8 & 2 & 0.6 \\
$\begin{array}{l}\text { Ischemic heart disease } \\
\text { Hypertension + diabetes mellitus }\end{array}$ & 2 & 6 & 2 & 1 & 0.06 \\
$\begin{array}{l}\text { Ischemic heart disease + } \\
\text { diabetes mellitus }\end{array}$ & 0 & 0 & 1 & 0 & 0.99 \\
$\begin{array}{l}\text { Ischemic heart disease + } \\
\text { hypertension }\end{array}$ & 0 & 1 & 0 & 1 & 0.94 \\
$\begin{array}{l}\text { Ischemic heart disease + } \\
\text { hypertension + diabetes mellitus }\end{array}$ & 1 & 2 & 1 & 0 & 0.68 \\
\hline $\begin{array}{l}\text { BMl: body mass index; IBW: ideal body weight; OW: overweight; OB: obese; MO: morbidly } \\
\text { obese. }\end{array}$ & & & & & \\
\hline
\end{tabular}

\section{Results}

We included 114 individuals in the study; they were distributed among BMI groups (Fig 1). Analysis of all preoperative variables revealed no statistically significant difference in the composition of the BMI groups (Table 1, Table 2, Table 3). Three patients in the ideal body weight group underwent supracostal punctures; all others were infracostal. Three patients in the morbidly obese group were positioned laterally; all others were in the prone position. Two patients in each of the ideal body weight and obese groups underwent a second-look nephroscopy.

Mean length of stay in days \pm SEM and stone-free rates for each group were not significantly different (Table 4). Intra-operative complication rates between groups were also comparable (Table 5). When complications were categorized according to the Clavien classification, there was only one Grade 3 complication, which occurred in the ideal body weight group and required surgical intervention (colonic injury). The remaining complications were Grade 1 or 2 . No patient required blood replacement and there were no deaths. No NTs were dislodged and no one developed a perirenal urinoma.

\section{Discussion}

Obese and morbidly obese patients present multiple treatment challenges for physicians and surgeons because they are more likely to have complex medical comorbidities, including orthopedic, cardiovascular, respiratory and metabolic derangements. Elevated BMI also confers a decreased life expectancy by as much as 20 years. ${ }^{15}$ For surgical patients, a high BMI increases the risk of complications and renders many surgical procedures more difficult and less satisfactory. ${ }^{6,11}$ Additionally, morbid obesity is an independent risk factor for mortality in patients undergoing surgery. ${ }^{16}$ With more and more overweight and obese people in many developed countries, medical and surgical practices must

\begin{tabular}{|c|c|c|c|c|c|}
\hline & IBW & OW & OB & MO & $p$ value \\
\hline $\begin{array}{l}\text { Preoperative } \\
\text { hemoglobin }\end{array}$ & $134(2.7)$ & $\begin{array}{l}140 \\
(2.8)\end{array}$ & $\begin{array}{c}142 \\
(2.1)\end{array}$ & $\begin{array}{c}144 \\
(6.5)\end{array}$ & 0.09 \\
\hline $\begin{array}{l}\text { Postoperative } \\
\text { hemoglobin }\end{array}$ & 124 (3.9) & $\begin{array}{c}122 \\
(3.4)\end{array}$ & $\begin{array}{l}130 \\
(2.2)\end{array}$ & $\begin{array}{l}129 \\
(7.5)\end{array}$ & 0.22 \\
\hline Preoperative GFR & $80(4.7)$ & $\begin{array}{c}76 \\
(4.1)\end{array}$ & $78(3)$ & $78(6.4)$ & 0.9 \\
\hline Postoperative GFR & $76(4.4)$ & $68(4)$ & $\begin{array}{c}73 \\
(3.1)\end{array}$ & $81(5.8)$ & 0.3 \\
\hline $\begin{array}{l}\text { Operating room } \\
\text { time (minutes) }\end{array}$ & $\begin{array}{l}44.6 \\
(2.4)\end{array}$ & $\begin{array}{l}43.4 \\
(4.9)\end{array}$ & $\begin{array}{c}47 \\
(2.6)\end{array}$ & $55(8.2)$ & 0.3 \\
\hline
\end{tabular}

prioritize safe and effective treatments for these patients.

Stone disease affects about $10 \%$ to $15 \%$ of North Americans and is more common in those with elevated BMI. $^{4,17}$ With various treatment modalities available, it is important to establish which methods of treatment are superior for obese patients. While ESWL is less invasive than PCNL, it is not as effective for stones $>20 \mathrm{~mm}$ and has limitations in large patients. ${ }^{18} \mathrm{PCNL}$, on the other hand, is the method of choice for larger stones and staghorn calculi. While this method is invasive, it is associated with more morbidity than ESWL, but less than open procedures. Whether PCNL is safe to perform in heavy patients has not been studied previously in Canada and has had mixed reports in the existing literature. ${ }^{19,20}$

To perform PCNL in obese individuals, careful attention must be paid to moving and positioning. For example, standard prone positioning presents challenges for ventilating heavy patients and impairs venous blood flow. ${ }^{21}$ Placement in the lateral decubitus position can alleviate some of these concerns and still allow access to the affected flank. Although there has been recent interest in supine positioning, there is no suggestion that it will facilitate treatment in obese patients. ${ }^{22}$ In addition to positioning, thicker subcuta-

\begin{tabular}{|c|c|c|c|c|c|}
\hline & IBW & OW & OB & MO & $p$ value \\
\hline $\begin{array}{l}\text { Intraoperative } \\
\text { complications }\end{array}$ & $3(8 \%)$ & $2(8 \%)$ & $1(2 \%)$ & $0(0 \%)$ & 0.55 \\
\hline $\begin{array}{l}\text { Post-op } \\
\text { complications }\end{array}$ & $1(3 \%)$ & $5(21 \%)$ & $4(10) \%$ & $2(20 \%)$ & 0.1 \\
\hline Stone free rate & $90 \%$ & $87 \%$ & $90 \%$ & $80 \%$ & 0.8 \\
\hline $\begin{array}{l}\text { Length of stay } \\
\text { (days) }\end{array}$ & $1.6(0.3)$ & $1.9(0.3)$ & $1.5(0.2)$ & $1.7(0.3)$ & 0.59 \\
\hline $\begin{array}{l}\text { Need of } \\
\text { re-admission }\end{array}$ & $0(0 \%)$ & $1(4 \%)$ & $3(8 \%)$ & $1(10 \%)$ & 0.3 \\
\hline
\end{tabular}


Alyami et al.

\begin{tabular}{|c|c|c|c|c|}
\hline & IBW & OW & OB & MO \\
\hline No. complications & 4 & 7 & 5 & 2 \\
\hline \multicolumn{5}{|l|}{ Clavien classification } \\
\hline Grade 1 & 1 & 2 & 0 & 0 \\
\hline Grade 2 & 2 & 5 & 4 & 2 \\
\hline Grade 3 & 1 & 0 & 0 & 0 \\
\hline $\begin{array}{l}\text { Type of complications } \\
\text { (by grade) }\end{array}$ & $\begin{array}{c}\text { Bleeding } \\
\text { Access failure } \\
\text { Colon injury } \\
\text { MI }\end{array}$ & $\begin{array}{c}\text { Respiratory failure } \\
\text { Pleural effusion } \\
\text { Pneumonia } \\
\text { UTI } \\
\text { Acute urinary retention x } 2 \\
\text { Bleeding }\end{array}$ & $\begin{array}{c}\text { UTI } \times 3 \\
\text { Hematuria } \\
\text { Acute urinary retention }\end{array}$ & $\begin{array}{c}\text { UTI } \\
\text { Pulmonary edema }\end{array}$ \\
\hline
\end{tabular}

BMI: body mass index; IBW: ideal body weight: OW: overweight; OB: obese; MO: morbidly obese; MI: myocardial infarction; UTI: urinary tract infection.

neous tissue makes access to the renal pelvis more difficult. Making larger incisions and employing longer instruments have been used successfully to overcome this problem. ${ }^{19,20}$

Despite the challenges, studies from the United States, United Kingdom and Egypt have demonstrated that PCNL can be performed safely and effectively in obese patients if extra precautions are taken to prevent potential respiratory and circulatory compromises. ${ }^{13,23,24}$ Here, we show for the first time in a Canadian patient population, that PCNL can be performed safely regardless of BMI.

Our study parameters and outcome measures are similar to those used by others. PCNL and percutaneous endopyelotomy were safely performed in individuals regardless of BMI and that success rates were comparable across all groups. ${ }^{21}$ This result concurs with three other retrospective studies that found no significant difference in stone-free rates, length of stay, change in hemoglobin and complication rates across the same four BMI groups defined in our study. ${ }^{13,25,26}$ Another small study revealed that length of stay was longer for individuals with normal body weight and that when treating a large stone burden, obese and morbidly obese patients were more likely to require a second-look nephroscopy. ${ }^{23}$ One group has also reported that complication rates are higher in obese patients. ${ }^{27}$ Another review showed that patients undergoing PCNL had similar outcomes and complication rates regardless of $\mathrm{BMI}$ and that the cost of treatment was not significantly different for any group. ${ }^{24}$

\section{Conclusion}

The present study is limited by its use of retrospective analysis, but the results are validated when compared to existing literature. Our outcomes for PCNL were statistically independent of BMI. This procedure is a safe and efficacious treatment of stone disease in patients of all sizes.

Competing interests: None declared.

This paper has been peer-reviewed.

\section{References}

1. Shields M, Carroll MD, Ogden CL. Adult obesity prevalence in Canada and the United States. National Center for Health Statistics 56(2011).

2. Statistics Canada. Table 105-0501: Body mass index, overweight or obese, self-reported, adult, by sex, provinces and territories in www.statcan.gc.ca, Vol. Catalogue no. 82-221-X (ed. CANSIM) (2011).

3. Flancbaum L, Choban PS. Surgical implications of obesity. Annu Rev Med 1998;49:215-34. http:// dx.doi.org/10.1146/annurev.med.49.1.215

4. Taylor EN, Stampfer MJ, Curhan GC. Obesity, weight gain, and the risk of kidney stones. JAMA 2005;293:455-62. http://dx.doi.org/10.1001/jama.293.4.455

5. Asplin JR. Obesity and urolithiasis. Adv Chronic Kidney Dis 2009;16:11-20. http://dx.doi. org/10.1053/i.ackd.2008.10.003

6. Choban PS, Flancbaum L. The impact of obesity on surgical outcomes: a review. J Am Coll Surg 1997;185:593-603. http://dx.doi.org/10.1016/S1072-7515(97)00109-9

7. Kurzer $E$, Leveillee $R$, Bird V. Obesity as a risk factor for complications during laparoscopic surgery for renal cancer: multivariate analysis. J Endourol 2006;20:794-9. http://dx.doi.org/10.1089/ end.2006.20.794

8. Balentine CJ, Wilks J, Robinson C, et al. Obesity increases wound complications in rectal cancer surgery. J Surg Res 2010;163:35-9. http://dx.doi.org/10.1016/i.jss.2010.03.012

9. Neligan PJ. Metabolic syndrome: anesthesia for morbid obesity. Curr Opin Anaesthesiol 2010;23:375-83. http://dx.doi.org/10.1097/AC0.0b013e328338caa0

10. El-Nahas AR, El-Assmy AM, Mansour 0 , et al. A prospective multivariate analysis of factors predicting stone disintegration by extracorporeal shock wave lithotripsy: the value of high-resolution noncontrast computed tomography. Eur Urol 2007;51:1688-1693; discussion 1693-4.

11. Vujovic A, Keoghane S. Management of renal stone disease in obese patients. Nat Clin Pract Urol 2007;4:671-6. http://dx.doi.org/10.1038/ncpuro0988

12. Pearle MS, Nakada SY, Womack JS, et al. Outcomes of contemporary percutaneous nephrostolithotomy in morbidly obese patients. J Urol 1998;160:669-73. http://dx.doi.org/10.1016/S0022$5347(01) 62750-2$

13. Koo $B C$, Burtt $G$, Burgess NA. Percutaneous stone surgery in the obese: outcome stratified according to body mass index. BJU Int 2004;93:1296-9. http://dx.doi.org/10.1111/i.1464-410X.2004.04862.x

14. Faerber GJ, Goh M. Percutaneous nephrolithotripsy in the morbidly obese patient. Tech Urol 1997;3:89-95.

15. Fontaine KR, Redden DT, Wang C, et al. Years of life lost due to obesity. JAMA 2003;289:187-93. http://dx.doi.org/10.1001/jama.289.2.187

16. Nasraway SA Jr, Albert M, Donnelly AM, et al. Morbid obesity is an independent determinant of death among surgical critically ill patients. Crit Care Med 2006;34:964-70; quiz 971. http://dx.doi. org/10.1097/01.CCM.0000205758.18891.70

17. Ramello A, Vitale C, Marangella M. Epidemiology of nephrolithiasis. J Nephrol 2000;13:S45-50.

18. Coz F, Orvieto $M$, Bustos $M$, et al. Extracorporeal shockwave lithotripsy of 2000 urinary calculi with the modulith SL-20: success and failure according to size and location of stones. J Endourol 2000; 14:23946. http://dx.doi.org/10.1089/end.2000.14.239

19. Curtis R, Thorpe AC, Marsh R. Modification of the technique of percutaneous nephrolithotomy in the morbidly obese patient. Br J Urol 1997;79:138-40. http://dx.doi.org/10.1046/i.1464410X.1997.129135.X

20. Giblin JG, Lossef S, Pahira JJ. A modification of standard percutaneous nephrolithotripsy technique for the morbidly obese patient. Urology 1995;46:491-3. http://dx.doi.org/10.1016/S0090$4295(99) 80260-X$ 
21. Yang RM, Bellman GC. Tubeless percutaneous renal surgery in obese patients. Urology 2004;63:103640; discussion 1040-1.

22. El Harrech Y, Ghoundale 0, Zaini R, et al. La NLPC en décubitus dorsal modifié: notre expérience. Can Urol Assoc J 2011;5:261-5. http://dx.doi.org/10.5489/cuaj.10168

23. Sergeyev I, Koi PT, Jacobs SL, et al. Outcome of percutaneous surgery stratified according to body mass index and kidney stone size. Surg Laparosc Endosc Percutan Tech 2007;17:179-83. http://dx.doi. org/10.1097/SLE.0b013e318051543d

24. Bagrodia A, Gupta A, Raman JD, et al. Impact of body mass index on cost and clinical outcomes after percutaneous nephrostolithotomy. Urology 2008;72:756-60. http://dx.doi.org/10.1016/i. urology.2008.06.054
25. El-Assmy AM, Shokeir AA, El-Nahas AR, et al. Outcome of percutaneous nephrolithotomy: effect of body mass index. Eur Urol 2007;52:199-204. http://dx.doi.org/10.1016/i.eururo.2006.11.049

26. Tomaszewski JJ, Smaldone MC, Schuster T, et al. Outcomes of percutaneous nephrolithotomy stratified by body mass index. J Endourol 2010;24:547-50. http://dx.doi.org/10.1089/end.2009.0431

27. Michel MS, Trojan L, Rassweiler JJ. Complications in percutaneous nephrolithotomy. Eur Urol 2007;51:899-906; discussion 906. http://dx.doi.org/10.1016/i.eururo.2006.10.020

Correspondence: Dr. Richard W. Norman, Suite 620, 5991 Spring Garden Rd., Halifax, NS B3H 1Y6; richard.norman@dal.ca 